\title{
Northwest Caucasian Language
}

National Cancer Institute

\section{Source}

National Cancer Institute. Northwest Caucasian Language. NCI Thesaurus. Code C160954.

A group of languages spoken in the northwestern Caucasus region, chiefly in three Russian republics (Adygea, Kabardino-Balkaria, Karachay-Cherkessia), the territory of Abkhazia, and Turkey, with smaller communities scattered throug hout the Middle East. 